BEATA KosmaLSKA

ORCID 0000-0003-4782-5926

Uniwersytet Gdański

\title{
EDUKACJA MEDIALNA W RODZINIE
}

Abstract. Kosmalska Beata, Edukacja medialna w rodzinie [Media Education in the Family]. Studia Edukacyjne nr 53, 2019, Poznań 2019, pp. 301-320. Adam Mickiewicz University Press. ISSN 1233-6688. DOI: $10.14746 /$ se.2019.53.17

This article discusses issues of forming and developing media skills in children in a family setting. Research on the role of media (mainly television) in a child's life has been conducted for many years and indicates a necessity to develop a child's media skills early (Izdebska, 1996, 2007; Kossowski 1999; Braun-Gałkowska 2003). There is a shortage of data on the role of parents in preparing children for formal media education (at school or preschool). It is the parents' responsibility to ensure that a child's first contact with media is handled properly. In light of this, the following questions arise: Do parents know about the risks, and also opportunities, resulting from the use of media by children? Do they teach children how to choose which media to use and manage the amount of time spent doing it? Do they teach children proper ways of using media for play? I attempt answering these questions by referencing opinions of media experts, psychologists and educators on the topic of media influence ("media childhood"), the significance of media education in developing media literacy in children, and by presenting the conclusions of my research that inspire further insightful analyses into media education of children at home.

Key words: media, television, family, media education

\section{Wprowadzenie}

Edukacja medialna stanowi konieczny element funkcjonowania i rozwoju współczesnych, zinformatyzowanych społeczeństw. Każdy człowiek ma kontakt z mediami, które wykorzystuje niemal we wszystkich sferach swojego życia. Edukację medialną należy uznać za niezbędną i obowiązkową część powszechnej edukacji człowieka. Brak wiedzy o mediach, sposobach ich użytkowania może prowadzić do cyfrowego wykluczenia. Dlatego, tak ważne wydaje się zagadnienie domowej formy edukowania medialnego dzieci. Rodzice ponoszą odpowiedzialność za pierwsze, prawidłowe kontakty dzieci 
z mediami. Powinni już w okresie wczesnego dzieciństwa przygotowywać najmłodszych do dalszych etapów formalnej edukacji medialnej. Ułatwi to dzieciom $\mathrm{w}$ przyszłości aktywne i racjonalne korzystanie z mediów, a tym samym ukształtuje ich kompetencje medialne.

\section{Społeczeństwo medialne}

Komunikowanie uznano za fundament, podstawę wszelkiej kultury. Dzięki doskonaleniu form komunikowania się ludzi możliwy był cywilizacyjny rozwój, a to w decydujący sposób przyczyniło się do powstania i rozwoju mediów. Upowszechnienie środków masowego przekazu jest rezultatem szeregu innowacji technologicznych. $W$ trakcie długotrwałego procesu rozwoju systemów międzyludzkiego porozumiewania się powstała formacja kulturowa, oparta na komunikowaniu masowym. Antonina Kłoskowska pojęcie kultury masowej odnosi do jednolitych form masowego uczestnictwa kulturalnego, jednolitych wytworów kultury, użytkowanych współcześnie przez wielkie rzesze odbiorców ${ }^{1}$. Warto przypomnieć, że Marshal McLuhan uznał media wizualne za nowe środowisko człowieka. Świat przez długie lata pozostawał w "galaktyce Gutenberga”, co znacznie ograniczało kontakty międzyludzkie, wyznaczało zastój w rozwoju cywilizacji. Dzięki elektronice człowiek zyskał poczucie przynależności i uczestnictwa w społecznej wspólnocie - „globalnej wiosce" ${ }^{2}$. Z kolei, Neil Postman współczesną kulturę określił pojęciem "technopol”, gdyż istotnym problemem obecnej cywilizacji jest natłok informacji i całkowite podporządkowanie współczesnego człowieka technice. Media tworzą pozorną, medialną świadomość odbiorców, a nowe technologie powodują zmianę jakościową środowiska człowieka³.

Od lat 80. XX wieku zaczęto używać terminu nowe media na określenie różnych, najnowszych technologii usprawniających komunikowanie, przede wszystkim upowszechnienie techniki komputerowej. Tak zwane stare media, czyli prasa, radio i telewizja wciąż pełnią ważną rolę w przekazywaniu informacji społecznej, jednak gwałtowny rozwój technologii informacyjnej powoduje, że w upowszechnianiu informacji wśród masowego odbiorcy coraz większe znaczenie przypisuje się Internetowi. Ryszard Kapuściński twierdził nawet, że "dzięki Internetowi rodzi się nowy świat, a rozpoczęte procesy zmian mogą zrujnować nasz cywilizacyjny, uporządkowany, lecz niezmiernie kruchy porządek"4.

\footnotetext{
1 A. Kłoskowska, Kultura masowa. Krytyka i obrona, Warszawa 2005, s. 288.

2 M. McLuhan, Wybór pism, Warszawa 1975, s. 183.

${ }^{3}$ N. Postman, Technopol - triumf techniki nad kultura, Warszawa 1995, s. 75-78.

${ }^{4}$ R. Kapuściński, Internet kontrolowany, Aktualności Telewizyjne, 1999, 2, s. 66.
} 
W przyszłości nieustannie będzie wzrastało znaczenie informacji w rozwoju społeczeństw. Obecnie kraje, które już osiągnęły najwyższy poziom rozwoju technologicznego środków informacji i komunikowania, są określane jako społeczeństwa informacyjne. Pojęcie to, wprowadzone w latach 70. minionego stulecia w Japonii i Stanach Zjednoczonych, wiązało się od początku nie tylko z technologiami komputerowymi, ale dotyczyło wizji przekształcania wszystkich sfer życia społecznego opartych na rozwoju struktur informacyjnych i telekomunikacyjnych. Jak podkreśla Stanisław Juszczyk, w latach 90. XX wieku pojawiły się terminy określające jeszcze dokładniej powstającą nową formację społeczną, a więc oprócz pojęcia społeczeństwa informacyjnego pojawiły się takie, jak społeczeństwo zinformatyzowane i społeczeństwo sieciowe $^{5}$. Ich wspólną cechą jest uznanie wiedzy, informacji za podstawowy czynnik przemian cywilizacyjnych. Tomasz Goban-Klas twierdzi, że społeczeństwem informacyjnym jesteśmy od początku swojego istnienia, a media rozumiane jako środki techniczne tylko zmieniły nasze możliwości komunikacyjne. Badacz proponuje bardziej adekwatne pojęcie, czyli społeczeństwo medialne (cywilizacja medialna) ${ }^{6}$.

Obecnie możemy obserwować zmieniające się w niezwykle szybkim tempie możliwości komunikacyjne. Dzięki Sieci stajemy się wszechobecni. W laptopie, tablecie, smartfonie, smartwatchu użytkownicy mają stały dostęp do wi-fi. Facebook, Instagram, Twitter, Skype, YouTube umożliwiają nieustanną wymianę obrazów, ikon, dźwięków, słów, filmów. Powoduje to przekształcenie nie tylko struktury społecznej, relacji społecznych, ale też współczesnej kultury. Jak twierdzi Len Masterman, dzięki mediom zdobywamy niezbędną wiedzę na przyszłość i dla przyszłości ${ }^{7}$. Jednakże, wśród badaczy pojawiają się wyraźne głosy zaniepokojenia przyszłością formułującego się społeczeństwa informacyjnego. Ryszard Tadeusiewicz dokonał analizy zjawiska „smogu informacyjnego", który przyrównał do smogu meteorologicznego. Podstawą tego porównania jest podobny stopień niepokoju o skutki wywołane tymi zjawiskami. Autor głównie skupia się na problemie nadmiaru informacji w przestrzeni medialnej i ich erozji jakościowej. Szczegółowo wyjaśnia, że smog to produkt uboczny procesu spalania, jak to określił „byle czego, byle gdzie i byle jak". Struktura smogu jest ogromnym zagrożeniem dla ludzi. Równie szkodliwy jest duszący nadmiar nieuporządkowanych, rozproszonych informacji w środowisku Internetu. Badacz podkreśla również, że ogromna ilość informacji jest bezużyteczna, nieprawdziwa, anonimowa i też ogromnie szkodliwa (treści agresywne, pornograficzne, pseudonaukowe). s. 11.

${ }^{5}$ S. Juszczyk, Człowiek w świecie elektronicznych mediów - szanse i zagrożenia, Katowice 2000,

6 T. Goban-Klas, Społeczeństwo medialne, Warszawa 2005, s. 46.

7 L. Masterman, Teaching the media, London 1990, s. 55. 
Stanowi to realne zagrożenie dla bardzo młodych odbiorców, którzy nie potrafią krytycznie ocenić docierających informacji. Zarówno smog meteorologiczny, jak też informacyjny jest dokuczliwy i niebezpieczny. Powszechnie dostępny Internet sprzyja zaśmieceniu informacyjnemu, co według autora powinno niepokoić nie tylko naukowców, ale przede wszystkim pedagogów, psychologów i wreszcie polityków ${ }^{8}$.

Badania mediów mają długoletnią tradycję, ale nie ma jednej koncepcji określającej rzeczywisty wpływ mediów na odbiorców. Część badaczy twierdzi, że media zawsze oddziałują na odbiorców, nawet gdy niezbyt uważnie z nich korzystają. Największy udział w poznaniu zjawiska funkcjonowania mass mediów mają podejścia socjologiczne, politologiczne, psychologiczne, semiologiczne i kulturowe. Dla pedagogów istotne jest przyjęcie perspektywy socjalizacji w badaniach nad rolą środków masowego przekazu, gdyż media masowe odgrywają istotną rolę w procesie nabywania (uwewnętrzniania) norm i wartości społecznych, stając się w ten sposób czynnikami socjalizacji jednostki ${ }^{9}$ Z kolei, inni badacze wskazują na możliwość istnienia szerokiej interdyscyplinarnej współpracy w ramach pola badawczego media studies, które wyznaczają cztery zasadnicze punkty, analizowane przez zestawy różnych nauk: poznanie, kultura, sfera społecznych zachowań oraz komunikacja ${ }^{10}$.

Interesujące badania oddziaływania środków masowego przekazu na odbiorcę dotyczą telewizji. Medium to doskonale wpisuje się we współczesną kulturę ikonograficzną, w której podstawą przekazu jest obraz. Antropologia oraz socjologia obrazu dają alternatywny sposób postrzegania świata i innych kultur. Telewizja przyczynia się do zwielokrotniania obrazów i znaków. Kultura medialna staje się częścią rzeczywistego świata. Do życia społecznego „wszczepia się teleobrazy i telemiejsca”, wykreowane przez narzędzia komunikacji globalnej ${ }^{11}$. Komputer, telewizja i inne nowe technologie zmieniają sytuację człowieka oraz jego środowisko życia. Jean Baudrillard twierdził, że człowiek poznaje obrazy miejsc, których w rzeczywistości nie ma, trudno rozpoznać co jest realne, a co jedynie wyobrażone ${ }^{12}$. Telewizyjne przekazy dla wielu odbiorców stają się, jak to określił Zbyszko Melosik, substytutem „rze-

${ }^{8}$ R. Tadeusiewicz, Smog informacyjny, Prace Komisji Zagrożeń Cywilizacyjnych, 1999, 2, s. 98-104, www.academia.edu [dostęp: 10.03.2019].

${ }_{9}$ T. Goban-Klas, Media i komunikowanie masowe. Teorie i analizy prasy, radia, telewizji i Internetu, Warszawa - Kraków 2001, s. 256.

${ }^{10}$ M. Rajewski, Media studies a antropologia środków przekazu - próba charakterystyki, [w:] Media studies. Refleksja nad stanem obecnym, red. K. Stępnik, M. Rajewski, Lublin 2008, s. 17-19.

${ }^{11}$ K. Banaszkiewicz, Nikt nie rodzi się telewidzem. Człowiek - kultura - audiowizualność, Kraków 2000, s. 108.

${ }_{12}$ Zob. J. Baudrillard, Świat wideo i podmiot fraktalny, [w:] Po kinie? Audiowizualność w epoce przekaźników elektronicznych, Wybór, wprowadzenie i opracowanie A. Gwóźdź, Kraków 1994, s. 254; tenże, Ameryka, przekł. R. Lis, Warszawa 1998, s. 178. 
czywistej rzeczywistości codziennego dnia". Widzowie często uważają swoje funkcjonowanie za mało interesujące, szare i bez wyjątkowych zdarzeń, więc treści programów umożliwiają im przeżywanie ekscytującego życia z ekranu telewizyjnego ${ }^{13}$.

W badaniach oddziaływania telewizji na człowieka wyodrębniły się dwa stanowiska. Pierwsze z nich charakteryzuje się niedocenianiem siły wpływu tego medium na odbiorców, podkreślając jedynie jego funkcję informacyjną i rozrywkową. Drugie stanowisko reprezentują poglądy o ogromnych możliwościach oddziaływania telewizji, a więc zarówno o jej pozytywnym i negatywnym wpływie na widza. Janusz Gajda ${ }^{14}$ twierdzi, że szczególnie atrakcyjne filmy czy programy telewizyjne odwołują się do właściwości tkwiących w każdym człowieku, czyli skłonności do naśladownictwa sposobu bycia, form zachowania, przyjmowania proponowanych interpretacji otaczającej rzeczywistości. Derrick de Kerckhove uważa, że dzięki mediom, przede wszystkim telewizji, tworzymy sztuczne środowisko społeczne, które jest przedpolem matrixu. Środowisko takie doprowadza do unifikacji zachowań, poglądów, stanowisk, zatarcia granicy między osobowością jednostki a przestrzenią społeczną ${ }^{15}$. Z kolei Małgorzata Bogunia-Borowska twierdzi, że telewizja tworzy schemat, który objaśnia i interpretuje porządek rzeczywistości. To rodzaj drogowskazu, mapy, przewodnika skomplikowanej codzienności. Od tego jak precyzyjnie skonstruowana jest ta mapa zależy wizja świata każdego $\mathrm{z}$ odbiorców $\mathrm{w}^{16}$.

\section{Dzieciństwo medialne}

Codzienną przestrzeń życia dzieci wypełnia obecność mediów. Dzieciństwo w społeczeństwie informacyjnym stwarza zarówno szanse rozwojowe, edukacyjne, jak i zagrożenia nie tylko dla rozwoju sfery emocjonalnej, ale także rozwoju całości osobowości dziecka. Według Jadwigi Izdebskiej,

(...) na kształt, obraz i jakość dzieciństwa mają wpływ poziom i możliwości rozwojowe, stan odczuwania przez dziecko potrzeb, a także środowisko, w którym ono żyje, to najbliższe, a także odległe, niewidzialne, pozytywne i wartościowo wychowawczo, jak również destrukcyjne ${ }^{17}$.

${ }^{13}$ Z. Melosik, Kultura popularna jako czynnik socjalizacji, [w:] Pedagogika, t. 2, red. Z. Kwieciński, B. Śliwerski, Warszawa 2003, s. 77.

${ }^{14}$ J. Gajda, Media w edukacji, Kraków 2002, s. 113.

${ }^{15}$ D. Kerckhove, Powłoka kultury. Odkrywanie nowej elektronicznej rzeczywistości, przekł. W. Sikorski, P. Nowakowski, Warszawa 1996, s. 27-38.

${ }^{16}$ M. Bogunia-Borowska, Fenomen telewizji. Interpretacje socjologiczne i kulturowe, Kraków 2012, s. 12.

${ }^{17}$ J. Izdebska, Dziecko osamotnione w rodzinie, Białystok 2004, s. 58. 
Dzięki dorosłym dzieci niemal od pierwszych chwil życia otoczone są mediami i multimediami. To stałe, medialne otoczenie powoduje naturalne wrastanie w świat nierzeczywistej rzeczywistości. Najważniejszą zaletą dostępu do komputerów (laptopów, tabletów) jest korzystanie z dostępnych gier i zabaw dydaktycznych (zestawy ćwiczeń, zagadek, kolorowanek, puzzli), które niewątpliwie rozwijają u dzieci zdolności logicznego myślenia, ułatwiają ćwiczenie pamięci, pobudzają do aktywności poznawczej, wreszcie - pełnią rolę atrakcyjnej zabawy. Mogą być dobrym przygotowaniem do nauki czytania i pisania. Nieumiejętne korzystanie $z$ tych mediów, bez wsparcia dorosłych, może z kolei stanowić źródło zagrożenia dla ich rozwoju emocjonalnego, poznawczego i społecznego. Uzupełnieniem katalogu mediów dostępnych dla dzieci jest również telefon komórkowy (smartfon). Nawet jeśli w okresie wczesnego dzieciństwa mają jeszcze nieco ograniczony dostęp do telefonów rodziców, to z pewnością permanentnie przygotowują się do jego posiadania. Producenci zabawek w swojej ofercie mają liczne propozycje zabawek interaktywnych dla najmłodszych dzieci, dedykowane maluchom już od szóstego miesiąca życia. Dorośli chętnie kupują dzieciom takie prezenty, stopniowo włączając najmłodszych w informacyjny świat dorosłych. Oto niektóre przykłady $\mathrm{z}$ oferty firmy Fisher Price: telefon $\mathrm{z}$ aparatem fotograficznym Chicco, Smartfon Smily Play, Smartfonik Malucha Fisher Price, Smartfon Cotoons Amoby (niebieski i różowy), Uczący smartfonik Nagraj wiadomość, Mój pierwszy tablet Clementoni, Bystry tablet Smily Play, E-book poczytaj mi bajeczkę Smily Play, Interaktywny pilot Szczeniaczka Uczniaczka. Oprócz tego firma proponuje bogaty wybór gier i zabaw online dla najmłodszych dzieci, na przykład: Literkowa zabawa ABC, Gra w zapamiętywanie, Nauka literek, Gra znajdź różnice, czy Odkrywanie kształtów ${ }^{18}$. Firma Fisher Price zachęca również do oglądania na swojej stronie internetowej edukacyjnych filmów animowanych dla dzieci. Są to kilkuminutowe formy, tematycznie związane na przykład z pobytem dzieci w przedszkolu, zabawami na świeżym powietrzu, czy też nauką piosenek. Dzięki takim ofertom w Sieci rodzice mogą korzystać z gotowych, łatwo dostępnych pomysłów na zabawy i naukę dla swoich dzieci. Skutkuje to również bardzo wczesnym kontaktem najmłodszych z komputerem i Internetem.

Najbardziej popularnym środkiem masowego komunikowania, ściśle związanym z życiem rodzinnym, jest nadal telewizja. Wśród badaczy istnieje zgodny pogląd, iż środowisko rodzinne, domowe jest naturalnym i stałym miejscem odbioru telewizji. W porównaniu z pozostałymi mediami, z których intensywnie korzysta się również poza domem rodzinnym, medium to stało się integralnym składnikiem codziennego funkcjonowania rodziny w stałej, nie-

\footnotetext{
${ }^{18}$ https://www.fisher-price.com [dostęp: 15.03.2019].
} 
zmiennej przestrzeni. Telewizor niemal w każdym domu zajmuje eksponowane miejsce, nie tylko z uwagi na rozmiary odbiornika, ale też ze względu na rolę pełnioną w życiu rodziny. Dla wielu odbiorców staje się on, jak to określił Tomasz Szkudlarek, „centralnym obiektem rytuału rodzinnego”19. David Morley uważa, że telewizja jest przede wszystkim domowym medium i jej odbiór ma miejsce $\mathrm{w}$ rodzinie. Te rodzinne uwarunkowania należy uznać za fundament bezpośrednich badań zjawiska odbioru telewizji ${ }^{20}$. Według Adama Lepy, telewizja jest jednym z najbardziej „domowych mediów”, które tak dalece wchodzi w codzienność odbiorców, że kontakt z nim staje się sposobem życia, formą przeżywania, czy stylem postępowania ${ }^{21}$. Również Jadwiga Izdebska wskazuje na charakterystyczną cechę telewizji, jaką jest domowość. Powoduje ona, że oglądanie telewizji odbywa się w domu rodzinnym, w gronie najbliższych osób ${ }^{22}$. John Ellis podkreśla, że środowisko rodzinne, domowe jest miejscem nieprzerwanego doświadczania oglądania telewizji. Dzięki telewizji następuje zetkniecie dwóch światów: wewnętrznego (domowego, rodzinnego, swojskiego) i zewnętrznego (mozaika zdarzeń świata zewnętrznego przedstawianych w nieskończonych wersjach) ${ }^{23}$. Poglądy o naturalnej obecności telewizji w życiu człowieka podziela również Ien $\mathrm{Ang}^{24}$, która podobnie jak John Ellis akcentuje kontekst domowego oglądania tego medium.

Jadwiga Izdebska uważa, że oprócz niewątpliwie szans edukacyjnych, jakie stwarza rodzinie telewizja, pojawiają się też zagrożenia, które dotyczą: dezorganizacji dnia, dezintegracji rodziny, zastępowania, wyręczania rodziców w realizacji przez nich niektórych funkcji opiekuńczo-wychowawczych. Wielogodzinne oglądanie telewizji przez dzieci skutecznie uniemożliwia im kontakty i zabawy z rówieśnikami ${ }^{25}$. Jak twierdzi David Buckingham, dzieci przeznaczają bardzo dużo czasu na oglądanie programów telewizyjnych, co pozostawia określone skutki dla rozwoju i kształtowania ich osobowości. Autor dodaje jednak stanowczo, że nie należy postrzegać telewizji oraz innych mediów jako wyłącznych, bezpośrednich sprawców wywoływania negatywnych zmian w rozwoju osobowości dziecka ${ }^{26}$. John C. Condry telewizję okre-

19 T. Szkudlarek, Media. Szkic z filozofii i pedagogiki dystansu, Kraków 1999, s. 77.

${ }^{20}$ D. Morley, Sposoby rodzinnego oglądania telewizji - zróżnicowanie ze względu na płeć, [w:] Gender w kinie europejskim i mediach, red. E. Ostrowska, Kraków 2001, s. 65.

${ }^{21}$ A. Lepa, Pedagogika mass mediów, Łódź 2000, s. 84-86.

${ }^{22}$ J. Izdebska, Rodzina, dziecko, telewizja. Szanse wychowawcze i zagrożenia telewizji, Białystok 1996, s. 52.

${ }^{23}$ J. Ellis, Visible Fictions: Cinema, Television, Video, London 1992, s. 115.

${ }^{24}$ I. Ang, Living Room Wars: Rethinking Media Audiences for a Postmodern World, London 1996, s. 22.

${ }^{25} \mathrm{~J}$. Izdebska, Mass media i multimedia - dominująca przestrzeń życia dziecka, [w:] Pedagogika społeczna, t. 2, red. E. Marynowicz-Hetka, Warszawa 2007, s. 301-302.

${ }^{26}$ D. Buckingham, Children Talking Television: The Making of Television Literacy, London 1993, s. 47. 
ślił mianem „,złodziejki czasu”, gdyż dzieci spędzają zbyt wiele godzin przed ekranem telewizyjnym i przez to zaniedbują inne czynności, być może ważniejsze dla ich rozwoju ${ }^{27}$. Wiliam L. Rivers i Cleve Mathews zwracają uwagę, że każdy przekaz medialny, jaki dociera do człowieka utrwala pewne zbiory norm, wzorców i ukształtowaną już wiedzę ${ }^{28}$.

Szczególnie wiele kontrowersji wśród twórców programów telewizyjnych, badaczy mediów, psychologów i pedagogów wywołuje problem przejmowania negatywnych wzorców zachowań przez widzów pod wpływem oglądanych scen agresji i przemocy. Badania prowadzone przez wiele lat przez L. Rowella Huesmanna i Leonarda D. Erona, zarówno eksperymentalne, jak i naturalne w środowisku dziecka, potwierdziły tę zależność dowodząc, iż dzieci oglądające przemoc w telewizji zachowują się częściej agresywnie $\mathrm{w}$ kontaktach z rówieśnikami ${ }^{29}$. Wiedza ta nie może być jednak dostępna wyłącznie dla medioznawców, psychologów i pedagogów, ale powinna za ich pośrednictwem docierać do rodziców. Jest to szczególnie ważne w sytuacji zalewu mediów treściami stanowiącymi zagrożenie dla prawidłowego rozwoju najmłodszych widzów. W ostatnich latach nasila się ekspansja patostreamów, a rodzice często nie mają wiedzy o serwisach internetowych, które $\mathrm{w}$ trakcie transmisji na żywo prezentują zachowania powszechnie uznane za szkodliwe społecznie (przemoc fizyczna, libacje alkoholowe, wulgaryzmy). Ponadto, czynności te stają się bardziej ekstremalne, im większe wpłaty pieniężne wpływają od odbiorców serwisu. Jest to bardzo niepokojące, zwłaszcza że obserwatorami patostreamów są coraz młodsze dzieci.

Należy stanowczo podkreślić, że dzieciństwo medialne jest wynikiem nie tylko nieświadomych działań dorosłych, lecz również tych w pełni świadomie podejmowanych decyzji. To przede wszystkim rodzice ponoszą odpowiedzialność za tworzenie rodzinnej, domowej przestrzeni, wyposażonej w dostępne na rynku media. Codziennie ich używają, starają się mieć dostęp do najnowszych rozwiązań technologicznych, co wiąże się z kupnem wciąż nowych modeli telefonów, tabletów, telewizorów. Spore grono rodziców to stali użytkownicy Facebooka, Instagrama, Twittera. W Polsce też coraz więcej rodzin korzysta z systemu Smart Home. Instalacja tak zwanego inteligentnego domu pozwala z użyciem telefonu, tabletu z zainstalowaną odpowiednią aplikacją sterować wszystkimi systemami w domu. Wydaje się więc, że nie ma możliwości wyłączenia dzieciństwa z medialnej przestrzeni. Dzieci od

${ }^{27}$ J.C. Condry, K. Popper, Telewizja - zagrożenie dla demokracji, przekł. M. Król, Warszawa 1996, s. 77.

${ }^{28}$ W.L. Rivers, C. Mathews, Etyka środków przekazu, przekł. J. Zakrzewski, E. Krasnodębska, Warszawa 1995, s. 48.

${ }^{29}$ L.R. Huesmann, L.D. Eron, Cognitive processes and the persistence of aggressive behavior, Aggressive Behavior, 1984, 10, 3, s. 245-248. 
najmłodszych lat przebywając $\mathrm{w}$ środowisku bogato wyposażonym $\mathrm{w}$ rozmaite urządzenia medialne, poznają najnowsze technologie i uczą się korzystania z dostępnych mediów.

\section{Kiedy rozpocząć edukację medialną w rodzinie?}

Teresa Hejnicka-Bezwińska zwraca uwagę, że żyjemy w czasach, kiedy ponownie pojawiają się pytania o sens edukacji w sytuacji „nowej nieprzejrzystości świata"30. Liczne rozważania na temat edukacji wskazują jej rolę w ułatwianiu ludzkości zrozumienia zglobalizowanego świata i dostrzegają szansę w rozwiązywaniu współczesnych zagrożeń cywilizacyjnych. Autorka podkreśla, że ważnym komponentem edukacji ogólnej jest edukacja medialna, która umożliwia zdobywanie kompetencji medialnych ${ }^{31}$.

Edukacja medialna to kształtowanie umiejętności korzystania z mass mediów, a także tworzenia i przekazywania informacji medialnych. Dotyczy ona zarówno aspektów kształceniowych, jak i wychowawczych. Edukacja medialna nie łączy się wyłącznie z przygotowaniem do optymalnego wykorzystania mediów w życiu społecznym, ale skupia na budowaniu świadomego, selektywnego i odpowiedzialnego posługiwania się środkami masowego przekazu w otaczającej, informatycznej rzeczywistości. Jak zaznacza Stanisław Juszczyk, obejmuje ona swym zasięgiem także technologię informacyjną, w ramach której opisuje się, analizuje i upowszechnia zastosowania edukacyjne mediów w różnych dziedzinach, przedmiotach i formach kształcenia szkolnego, ustawicznego i zdalnego. W działaniach edukacyjnych powinno się wykorzystywać prasę, radio, telewizję, wideo, komputery, multimedia i sieci informacyjne ${ }^{32}$.

Edukację medialną można rozpatrywać z dwóch perspektyw: formalnej i nieformalnej. Pierwsza najczęściej związana jest z realizacją celów edukacji medialnej, prowadzona w ramach instytucji na zajęciach obowiązkowych i fakultatywnych. Nieformalna przebiega w różnorodnych, pozaszkolnych strukturach środowiska społecznego. Najważniejsze z nich, bo rozpoczynające edukację medialną i przygotowujące do kształtowania kompetencji medialnych przez inne podmioty środowiskowe, to oczywiście środowisko rodzinne. Obecnie pozyskiwanie wiedzy o mediach, przygotowanie do korzystania $\mathrm{z}$ ich, rozumienie przekazów medialnych powinno odbywać się znacznie wcześniej, zanim rozpoczną się planowane zajęcia edukacyjne. Dzieci od najmłodszych lat stykają się z różnymi środkami masowego przekazu

${ }^{30}$ T. Hejnicka-Bezwińska, Pedagogika społeczna w kontekscie sporów o przedmiot $i$ strukturę pedagogiki oraz jej związki z innymi dyscyplinami naukowymi, [w:] Pedagogika społeczna, s. 158.

31 J. Izdebska, Mass media i multimedia, s. 532-533.

32 S. Juszczyk, Człowiek w świecie elektronicznych mediów, s. 51. 
w różnorodnych sytuacjach nieformalnych. Rodzinna edukacja medialna jest realizowana spontanicznie, ale też przez działania zamierzone, co pozwala dziecku na stopniowe zdobywanie kompetencji medialnych. Wysiłki rodziców powinny być wspomagane przez wiele instytucji wychowania intencjonalnego i nieintencjonalnego (przedszkole, szkoła, organizacje społeczne, instytucje pozaszkolne, Kościół).

Liczne badania ${ }^{33}$ wykazały, że dzieci bardzo wcześnie rozpoczynają interesować się mediami. Już około czwartego miesiąca życia wyraźnie reagują na dźwięk, strumień światła i kolory ekranu telewizyjnego. Na przełomie drugiego i trzeciego roku życia dzieci potrafią określić swoje ulubione programy. Widzowie $\mathrm{w}$ wieku przedszkolnym około czwartego, czasami piątego roku życia zaczynają dostrzegać różnicę między światem telewizyjnym a realną rzeczywistością. Filmy, kreskówki animowane potrafią ocenić jako programy przedstawiające nie istniejący realnie świat, ale wierzą jeszcze, że cała "reszta telewizji” jest realna. Najmłodsi widzowie w ciągu wielogodzinnego oglądania telewizji stopniowo uczą się też różnych gatunków telewizyjnych. Około siódmego roku życia potrafią już zrozumieć, że treści bajek, filmów są wymyślone i wyreżyserowane. U dzieci zauważono również występowanie zjawiska tak zwanego słuchowego odbioru programów telewizyjnych przez nich. Telewizor "towarzyszy” dzieciom w trakcie zabawy i nawet jeśli nie patrzą na jego ekran, to z pewnością ponownie skierują na niego swoją uwagę, kiedy dotrze do nich interesujący dźwięk.

Zdaniem Marii Braun-Gałkowskiej i Iwony Ulfik, obowiązkiem rodziców jest kontrola oglądanych przez dzieci programów telewizyjnych, gdyż poważnie wpływa to na ich zachowanie bieżące oraz jakimi ludźmi będą w przyszłości ${ }^{34}$. Niepokój budzi oglądanie przez dzieci programów telewizyjnych przeznaczonych dla widzów dorosłych. W codziennych kontaktach młodych widzów z telewizją ważne jest, aby odbierane przekazy były dostosowane do ich wieku i możliwości percepcyjnych. Dwight Macdonald uważa, że dzieci mają zbyt wcześnie dostęp do rozrywek dorosłych (na przykład telewizji), a nadmiar bodźców, napięcia, podniet zawartych w przekazach medialnych powoduje wiele zmian w osobowości dzieci, które według badacza za szybko dojrzewają. Bezrefleksyjna konsumpcja treści oferowanych przez media oznacza niebezpieczeństwo zerwania kontaktów z rzeczywistością i zamknięcie się w określonym, samowystarczalnym świecie ${ }^{35}$. Od-

${ }^{33}$ J.C. Wright i in., Young children's Perceptions of Television Reality: Determinants and Developmental Differences, Developmental Psychology, 1994, 30, 2, s. 230-238.

${ }^{34}$ M. Braun-Gałkowska, I. Ulfik, Zabawa w zabijanie. Oddziatywanie przemocy prezentowanej w mediach na psychikę dzieci, Warszawa 2000, s. 167.

${ }^{35}$ D. Macdonald, Teoria kultury masowej, [w:] Kultura masowa, Wybór, przekład, przedmowa Cz. Miłosz, Kraków 2002, s. 26. 
mienne poglądy reprezentują Bob Hodge i David Tripp, którzy twierdzą, że dziecko, wbrew powszechnej opinii, bardzo wcześnie zaczyna rozumieć "dorosłe programy". Najmłodsi odbierają programy telewizyjne przeznaczone dla dorosłego widza, zgodnie z własną ciekawością i wyobraźnią ${ }^{36}$.

Paweł Kossowski podjął próbę podsumowania różnorodnych podejść teoretycznych do problematyki dziecka i telewizji oraz interpretacji wyników badań empirycznych naukowców z różnych krajów, w tym także badaczy polskich. Zdaniem autora, z najważniejszych ustaleń wynika, że dzieci zaczynają obecnie oglądać telewizję bardzo wcześnie, średnio w drugim roku życia; najwierniejszymi widzami telewizji są dzieci z rodzin ubogich oraz mające gorsze wyniki w nauce; mali odbiorcy oglądają telewizję w sposób nawykowy, nie mając jednocześnie kompetencji komunikacyjnych; telewizja dostarcza dzieciom wzorców do naśladowania, które przejmują i ujawniają w swym zachowaniu; dzieci bardzo często oglądają telewizję „zamiast czegoś"37.

Michele Elliott uważa, że rodzice nigdy nie mogą być pewni, czy ich dzieci nie zetkną się z nieodpowiednim dla nich przekazem medialnym. Dlatego, autorka podaje rodzicom kilka ważnych wskazówek:

- rodzice zawsze powinni czytać opis i recenzje programów oraz filmów telewizyjnych;

- jeśli dorosły ma wątpliwości odnośnie tematyki filmu, powinien najpierw obejrzeć go sam, uznać czy jest dla dziecka odpowiedni i dopiero pozwolić na jego odbiór;

- należy wytłumaczyć dziecku, dlaczego rodzice nie lubią i nie chcą, żeby oglądało niewłaściwe dla niego programy telewizyjne;

- jeżeli dziecko obejrzało niezrozumiały dla niego program lub film, dorośli powinni wytłumaczyć mu, że prawdziwe życie wygląda zupełnie inaczej;

- rodzice muszą mieć też wzajemną pewność, czy współmałżonek nie zezwala dziecku na oglądanie treści przeznaczonych wyłącznie dla dorosłych;

- należy zawsze upewnić się, że osoba zajmująca się twoim dzieckiem nie pozwala mu na oglądanie niewłaściwych treści;

- trzeba sprawdzać, jakie programy i filmy telewizyjne dziecko ogląda poza domem;

- ważne jest nauczenie dziecka protestowania przeciwko nakłanianiu go do oglądania niewłaściwych treści ${ }^{38}$.

Wytyczne Michele Elliott można więc uznać za elementy rodzinnej edukacji medialnej. Anna Sugier-Szerega również twierdzi, że to dorośli powinni

${ }^{36}$ B. Hodge, D. Tripp, Children and Television: A Semiotic Approach, Cambridge 1986, s. 174-179.

37 P. Kossowski, Dziecko i reklama telewizyjna, Warszawa 1999, s. 54-57.

${ }^{38}$ M. Elliott, Jak dbać o bezpieczeństwo dziecka. Praktyczne rady dla rodziców, przekł. K. Kozubal, Warszawa 1997, s. 126-127. 
wyznaczać jasne granice korzystania z mediów, przekazywania świata kultury offline, który media tylko uzupełniają ${ }^{39}$.

W społeczeństwie informacyjnym $w$ dziedzinie edukacji medialnej ważne i konieczne są uregulowania prawne oraz działania organizacji społecznych. W 2007 roku pojawiła się dyrektywa audiowizualna, w której Unia Europejska (UE) wezwała kraje członkowskie do zajęcia się kwestią edukacji medialnej. Jeden z kierunków działania dotyczy kształtowania kompetencji w zakresie obsługi, korzystania, odbioru i wykorzystywania przekazów medialnych. Kompetencje medialne to nie tylko zdolność do korzystania z mediów, ale też rozumienie i krytyczna ocena różnych aspektów mediów oraz ich treści, jak też porozumiewanie się $\mathrm{w}$ różnych kontekstach. Jest to podstawowa umiejętność istotna dla młodszego pokolenia i dorosłych. UE uznaje kompetencje medialne za ważny czynnik aktywności obywatelskiej w dzisiejszym społeczeństwie informacyjnym. W konkluzjach Rady Europy z 30 maja 2016 roku w sprawie rozwijania (przez kształcenie i szkolenie) umiejętności korzystania z mediów i umiejętności krytycznego myślenia podkreślono, że w epoce Internetu, mediów społecznościowych kompetencje medialne są wyjątkowo istotne, ważniejsze niż kiedykolwiek przedtem i muszą być integralnym elementem kształcenia oraz szkolenia na wszystkich poziomach. Kompetencje medialne są w oczywisty sposób związane koncepcją lifelong learning (LLL). Jest ona wiodącym elementem Strategii Lizbońskiej, ogłoszonej w 2000 roku przez Unię Europejską. Zgodnie z jej treścią, edukacja stanowi jeden z najważniejszych czynników prowadzących do tego, aby gospodarka UE mogła stać się najbardziej konkurencyjną i dynamiczną gospodarką na świecie. Ludność natomiast ma się stać społeczeństwem wiedzy. Idea LLL dotyczy zarówno rozwoju indywidualnego, jak i rozwoju cech społecznych we wszystkich formach i kontekstach, w systemie formalnym i nieformalnym. Nacisk położony jest na zachęcanie do nauki przez całe życie, już od wczesnego dzieciństwa. Za działania priorytetowe $\mathrm{w}$ tym zakresie uznano:

- Nadanie wysokiej rangi uczeniu się.

- Zwiększenie powszechnego dostępu do informacji i doradztwa dotyczącego możliwości edukacyjnych.

- Zwiększenie inwestowania w uczenie się.

- Przybliżanie uczącym się możliwości edukacyjnych.

- Upowszechnianie umiejętności podstawowych.

- Rozwój innowacyjnych koncepcji uczenia się/nauczania.

Idea edukacji przez całe życie pojawiła się na początku XX wieku. Jako koncepcja została ukształtowana w latach 70. XX wieku, z aktywnym zaan-

39 A. Sugier-Szerega, Ksztattowanie kompetencji medialnej u dzieci w wieku przedszkolnym szanse, trudności, ograniczenia, [w:] Edukacja medialna w dobie wspótczesnych zmian kulturowych, społecznych i technologicznych, red. A. Ogonowska, G. Ptaszek, Kraków 2015, s. 29. 
gażowaniem UNESCO. Podstawowa teza lifelong learning zakłada, że „każdy człowiek ma prawo i powinien uczyć się przez całe swoje życie”. W Strategii Lizbońskiej zawarto jej definicję: „wszelkie działania związane z uczeniem się przez całe życie, zmierzające do poprawy poziomu wiedzy, umiejętności i kompetencji w pespektywie osobistej, obywatelskiej, społecznej i/lub związanej z zatrudnieniem ${ }^{40}$.

Jednym z zaleceń Rady Europy jest przygotowanie młodych widzów do odbioru programów telewizyjnych. Dlatego tak ważna jest edukacja medialna społeczeństwa, w tym przede wszystkim dzieci. Edukacja medialna powinna być prowadzona permanentnie od najmłodszych lat życia w rodzinie, szkole, środowisku lokalnym. Polega ona na rozwijaniu kompetencji w zakresie posługiwania się językiem mediów, rozumiana jako wprowadzenie w kulturę medialną w celu przygotowania dzieci do krytycznego, aktywnego, selektywnego odbioru programów telewizyjnych ${ }^{41}$. Przykładem realizacji zaleceń Rady Europy mogą być działania podjęte przez Wyższą Radę Audiowizualną we Francji (CSA). Na jej stronie internetowej edukacja medialna wymieniona jest jako jeden z sześciu aspektów ochrony małoletnich użytkowników mediów.

Ochrona małoletnich użytkowników mediów w rozumieniu CSA to:

1. Ochrona przed szkodliwymi treściami.

2. Ochrona przed presją reklamową.

3. Ochrona małoletnich uczestników audycji i reklam.

4. Zagwarantowanie oferty programowej odpowiedniej dla małoletnich odbiorców.

5. Ochrona zdrowia młodej publiczności.

6. Edukacja medialna (edukacja do mediów).

Interaktywny serwis przeznaczony jest dla dorosłych i dzieci, w którym z użyciem prostego, skrótowego języka objaśnia się główne zasady bezpiecznego i rozsądnego korzystania z mediów oraz ostrzega przed zagrożeniami. Towarzyszą temu hasła, na przykład: „Dzieci nie widzą w telewizji tego samego co my", skierowane do dorosłych i służące zwróceniu uwagi na ryzyko pozostawienia dzieci samych przed włączonym ekranem. Z kolei hasło „Wszyscy bądźmy odpowiedzialni przed ekranem”, przeznaczone jest głównie dla dzieci, a wykorzystano w nim postać znanej najmłodszym odbiorcom maskotki (pluszaka), która modulowanym głosem, w humorystyczny sposób radzi dzieciom, jak właściwie zachowywać się przed ekranem ${ }^{42}$.

W Polsce Krajowa Rada Radiofonii i Telewizji (KRRiT) określiła rozumienie pojęcia edukacji medialnej i kompetencji medialnych. Pierwszy termin oznacza

\footnotetext{
${ }^{40}$ https://www.pi.gov.pl, [dostęp: 17.03.2019].

${ }^{41}$ http://www.europarl.europa.eu, [dostęp: 17.03.2019].

${ }^{42}$ http://www.krrit.gov.pl, [dostęp: 18.03.2019].
} 
„proces kształtowania i umiejętności świadomego i krytycznego korzystania ze środków społecznego przekazu we wszystkich grupach społecznych i wiekowych. Proces edukacji medialnej to działania, które powinny trwać przez całe życie, ponieważ formy i technologie przekazu ulegają zmianom, a ponadto społeczeństwo także ulega ciągłym przeobrażeniom”. Z kolei „w procesie edukacji medialnej zdobywa się kompetencję medialną, która charakteryzuje świadomego i aktywnego odbiorcę przekazu medialnego. Odbiorca ten, rozumiejąc stosowane $\mathrm{w}$ mediach mechanizmy tworzenia i selekcji informacji, potrafi nie tylko skutecznie i bezpiecznie korzystać z mediów, to znaczy krytycznie ocenić odbieraną treść, $w$ tym reklamy i inne przekazy handlowe, ale także twórczo używać środków przekazu w codziennym życiu" ${ }^{43}$.

Ważnym dokumentem okazał się wydany 17 lipca 2018 roku przez KRRiT Komunikat w sprawie ochrony dzieci i młodzieży, który określono jako priorytet i zadanie strategiczne. Wytyczył on przede wszystkim standardy obowiązujące dostawców usług medialnych w zakresie ochrony małoletnich przed szkodliwym oddziaływaniem treści medialnych. KRRiT wykonując swoje ustawowe kompetencje, ma przede wszystkim wspierać rodziców i opiekunów w ochronie dzieci przed negatywnym wpływem treści programowych.

\section{Syntetyczny raport z badań - najważniejsze wyniki}

Badania, które przeprowadziłam w marcu 2019 roku w Trójmieście dotyczyły podejmowania przez rodziców działań edukacyjnych w kontekście korzystania ich dzieci z mediów dostępnych w rodzinnym domu. Ich wyniki miały odpowiedzieć na główny problem badawczy: $W$ jaki sposób rodzice uczą dzieci korzystania z mediów? Ważne było ustalenie, z jakich mediów korzystają dzieci, czy mają do nich selekcjonowany dostęp i czy wykorzystują je w zabawie.

Wywiady przeprowadziłam $\mathrm{z}$ rodzicami (w wieku od 30. do 36. lat; $\mathrm{w}$ ośmiu rodzinach oboje rodzice $\mathrm{z}$ wyższym wykształceniem, w czterech tylko jeden rodzic $z$ takim wykształceniem, a drugi ze średnim, w trzech rodzinach oboje rodzice mieli wykształcenie średnie) stanowiącymi piętnaście rodzin z dziećmi w wieku przedszkolnym (4 i 5 lat), które nie uczęszczają do placówek wychowania przedszkolnego. Ten celowy dobór badanych rodzin gwarantował ocenę wyłącznej roli rodziców w początkowym etapie kształtowania kompetencji medialnych u najmłodszych odbiorców, jeszcze bez wpływu formalnej edukacji.

43 Tamże. 
W badanych rodzinach dzieci korzystają przede wszystkim z telewizji. Dostęp do komputera stacjonarnego rodziców czy starszego rodzeństwa we wszystkich domach był minimalny, wyłącznie w obecności rodziców. Natomiast, dorośli pozwalają dzieciom korzystać z tabletów (jak to określiła część rodziców - tablet jest urzadzeniem pod stała kontrola). Rodzice nauczyli swoje dzieci jedynie podstawowych umiejętności posługiwania się tymi urządzeniami. Nie pozwalają im na niekontrolowane korzystanie z tabletów, na przykład samodzielne otwieranie przeglądarek internetowych. W jedenastu rodzinach tablety służą rodzicom głównie do szybkiego uzyskania potrzebnych informacji, ale ponieważ są to urządzenia przenośne, często zdarza się, że dzieci mogą oglądać bajki, korzystać z gier i zabaw komputerowych w sytuacjach braku dostępu do telewizji, odtwarzaczy DVD czy Blu-Ray. Większość rodziców podkreślała, że ich dzieci używają tabletów przede wszystkim w czasie spotkań rodzinnych poza domem i podczas wyjazdów wakacyjnych. Poza tym, rodzice udostępniają sporadycznie swoim dzieciom telefony do rozmów z członkami swojej rodziny, bądź bliskimi znajomymi, czasami do gier, jako „wypełniacz czasu”, na przykład oczekując w kolejce na wizytę u lekarza. Rodzice umiejętność obsługi telefonu (smartfona) postrzegają jako oznakę wyjątkowych zdolności swoich dzieci. $\mathrm{Na}$ taki aspekt zwróciło uwage sześciu rodziców. Tylko w jednej rodzinie czterolatek ma dostęp do smartwatcha starszego rodzeństwa, ale rodzice zapewniali, że ich dziecko nie jest jeszcze zainteresowane tym urządzeniem, gdyż postrzega je jako nowoczesną wersję typowego zegarka. Natomiast, telewizja to medium, z którego korzystają wszystkie dzieci w badanych rodzinach, a rodzice określają te kontakty jako bezpieczne i w pełni przez nich kontrolowane. Ponadto, wszyscy dorośli są przekonani, że całkowity brak kontaktów z telewizją może w znacznym stopniu ograniczyć wiedzę dzieci o świecie, o dziecięcych modach na przykład na gadżety filmowe (zabawki, breloki, czy koszulki z bohaterami kreskówek), a to z kolei może utrudniać im kontakty z rówieśnikami. Dodają również, że nie da się całkowicie wyeliminować oglądania telewizji z ich rodzinnego życia i swoją kontrolę oglądanych treści przez dzieci uważają za dobrą i wystarczającą, gdyż deklarują swoją częstą obecność podczas oglądania telewizji przez dzieci.

Moje badania potwierdziły, że pojęcie edukacji medialnej nie jest w pełni zrozumiałe dla rodziców. Kojarzą je wyłącznie z nauczaniem szkolnym i sądzą, że nie dotyczy ono telewizji, a tylko komputera. Swoją rolę w kontaktach dzieci z telewizją postrzegają przede wszystkim jako „kontrolerów” czasu przeznaczonego na oglądanie programów telewizyjnych i selekcji kanałów telewizyjnych. Tylko jedna rodzina pojęcie to określiła jako świadomy dobór programów telewizyjnych, z naciskiem na wspólne oglądanie telewizji $\mathrm{z}$ dzieckiem i $\mathrm{w}$ razie potrzeby tłumaczenie mu niezrozumiałych treści. 
Większość badanych rodziców (dziesięć rodzin) pozwala dzieciom oglądać telewizję dwie lub trzy godziny dziennie. Tylko w jednej rodzinie dzieci mają ograniczony dostęp do korzystania z telewizji do jednej godziny dziennie. W pozostałych domach mali odbiorcy mogą oglądać programy telewizyjne nawet do czterech lub pięciu godzin dziennie. Niepokój może budzić fakt, iż większość badanych rodziców uważa, że oglądane przez dzieci bajki, filmy familijne są $w$ pełni bezpieczne, jeśli emitowane są $w$ kanałach dziecięcych. Jedynie $\mathrm{w}$ trzech rodzinach dorośli dostrzegli pewne niebezpieczeństwa $\mathrm{w}$ prezentowanych filmach animowanych japońskiej oraz amerykańskiej produkcji i starają się wybierać dla swoich dzieci inne treści. W trzynastu rodzinach rodzice przyznali, że ich pociechy często towarzyszą im $w$ recepcji programów nadawanych w godzinach wieczornych, uznając, że „wiadomości" czy "informacje” to dopuszczalne i niezagrażające dzieciom przekazy. Wszyscy dorośli w swoich wypowiedziach podkreślili, że na przykład okres świąteczny pozwala na przeznaczenie większej ilości czasu na oglądanie telewizji, gdyż wówczas programy w ciągu całego dnia są "bezpieczne” dla dzieci, mają szczególny charakter i nie budzą niepokoju rodziców. Wszyscy rodzice nie dostrzegają też problemu odbioru przez swoje dzieci reklam telewizyjnych, które poprzedzają nawet wybrane przez nich programy. Zgodnie uważają, że zagrażające rozwojowi najmłodszych widzów są jedynie reklamy emitowane w późnych godzinach wieczornych. Można te wypowiedzi uznać za przejaw działania tak zwanego efektu trzeciej osoby. Koncepcja ta zakłada, że odbiorcy uważają, iż inni ludzie są bardziej niż oni podatni na zawarte w mediach treści. Odbiorcy oceniają siebie jako bardziej odpornych na negatywne oddziaływanie mediów. Jak twierdzi Maciej Mrozowski, powoduje to „spaczone postrzeganie rzeczywistości" ${ }^{44}$.

W ośmiu rodzinach dorośli przyznali, że niekiedy dzieci namawiają ich do kupna reklamowanych $\mathrm{w}$ telewizji produktów. Jeden rodzic określił to jako znak wspótczesnych czasów. Inni rodzice uznali, że ułatwia im to kupno na przykład prezentów dla swoich dzieci. W siedmiu rodzinach okazało się, że ich pociechy bardzo często oglądają telewizję przebywając u swoich dziadków, krewnych lub przyjaciół. Dorośli uważają, że na to nie mają już wpływu i z pewnością nie należy się tym martwić. Jeden rodzic stwierdził nawet, że brak telewizora w domu (rodzinie) to przejaw niezrozumiałej mody, podobnie jak wegetarianizm. Poza tym, rodzice sądzą, że dzieci w wieku przedszkolnym jeszcze nie rozumieją zbyt wielu emitowanych treści, więc nie może to negatywnie na nie oddziaływać. Jak już wcześniej wspomniałam, tylko w jednej z badanych rodzin dorośli zdają sobie sprawę, że treści medialne mogą stanowić

${ }^{44}$ M. Mrozowski, Efekt trzeciej osoby, czyli postrzeganie podatności innych ludzi na wptyw mediów masowych, Studia Medioznawcze, 2003, 4(14), s. 15-16. 
zagrożenie dla rozwoju swojego dziecka i starają się sporadycznie pozwalać na korzystanie z telewizji, kiedy uznają, że przekaz telewizyjny jest wyjątkowo wartościowy. Również tylko w tej rodzinie dzieci bardzo rzadko mają dostęp to tematycznych, interaktywnych gier i zabaw. Pozostali rodzice zgodnie twierdzili, że domowe media bardzo ułatwiają i pomagają im wypełnić czas wolny dzieci, wręcz zastępują ich na przykład w wyszukiwaniu atrakcyjnych dla najmłodszych zabaw i gier. Prawie we wszystkich rodzinach (dwunastu) dorośli mają doskonałą wiedzę o dostępności na rynku gier komputerowych dla dzieci w wieku przedszkolnym. W czasie wywiadów okazało się też, że dorośli bardzo dobrze orientują się $\mathrm{w}$ rankingach najlepszych programów i gier edukacyjnych. Chętnie uczą swoje dzieci korzystania z nich, uznając to za formę domowo-rodzinnej zabawy. Przeglądają wspólnie z dziećmi strony edukacyjne, korzystają z YouTube'a. Niektórzy rodzice kupują gry dla swoich dzieci $\mathrm{w}$ formie prezentów, ale też pozyskują je wymieniając się nimi ze znajomymi. W trakcie wywiadów ustaliłam, że ulubione przez dzieci, jak i rodziców gry to: „Wesołe przedszkole Koziołka Matołka”, „Wesołe przedszkole Bolka i Lolka”, "60 minut smerfowych przygód”, „Bob Budowniczy: Bob buduje park”, "ABC z Reksiem”, ,Noddy szykuje się do szkoły” i „Piosenki dla dzieci Smoka Edzia". Niektóre gry i zabawy edukacyjne dostępne są na YouTubie, a z nich najchętniej rodzice wybierają dla swoich dzieci: serię zabaw „Ubu” i „Świnka Peppa” oraz gry „Ślimak Bob” i „Lego”. Wszystkie uczą dzieci logicznego myślenia, dopasowywania kształtów, kolorów. Dzieci poznają na przykład świat roślin, zwierząt $\mathrm{w}$ formie zagadek słownych czy puzzli, uczą się literek i cyferek, a to stanowi przygotowanie do nauki szkolnej. Jak przyznali rodzice, wiele z tych gier wybierają kierując się również wspomnieniem oglądanych w dzieciństwie bajek i kreskówek. Część rodziców korzysta z gier wykorzystując komputer stacjonarny lub nagrywarkę DVD w połączeniu z telewizorem, niektórzy udostępniają dzieciom tablety. W badanych rodzinach rodzice zachęcają też dzieci do wykorzystywania w zabawie takich gier planszowych, jak na przykład: „Grzybobranie”, „Skaczące Czapeczki”, "Kim jestem?”, „Mówiące Pióro". Jednakże, większość dzieci (w dziesięciu rodzinach) wyraźnie preferuje korzystanie z gier komputerowych.

W trakcie badań okazało się, że badani rodzice sami nie doświadczyli rodzinnej edukacji medialnej, a także potwierdzili, że w ich formalnej edukacji o mediach (w szkole) brakowało wiedzy o negatywnym oddziaływaniu telewizji na odbiorców, szczególnie na dzieci i młodzież. Żadna z badanych rodzin nie potrafiła też wskazać źródła, które mogłoby obecnie stanowić dla nich wskazówkę, poradę, czy ostrzeżenie przed nieumiejętnym wkraczaniem dzieci w świat mediów. Swoją troskę i zabezpieczenie dzieci przed szkodliwym oddziaływaniem treści przekazów medialnych opierają głównie na własnych przeżyciach, odwołują się do swojej wrażliwości, czasem intuicji. 
Jak ustaliłam, nauka dzieci korzystania z mediów w badanych przeze mnie rodzinach nie ma charakteru intencjonalnego, rodzice nie traktują jej jako zaplanowanego działania edukacyjnego. Odbywa się to niejako przy okazji wykorzystywania domowych urządzeń medialnych do zabaw w czasie wolnym, a także jest to wynik naturalnej potrzeby poznawania otaczającej rzeczywistości przez najmłodszych. Rodzice uczą dzieci jedynie podstawowych umiejętności ich obsługi, pozwalają im na dostęp do wszystkim domowych urządzeń (z pewnym ograniczeniem korzystania z komputerów stacjonarnych), bez wyraźnej selekcji doboru konkretnych mediów do określonych aktywności dzieci. Najmniej kontrolowanym przez rodziców medium okazała się telewizja, która wymaga niewiele wysiłku i umiejętności, aby z niej korzystać, a to sprzyja szybkiemu włączaniu najmłodszych w świat odbiorców przekazów medialnych. $\mathrm{Z}$ pewnością dzieci $\mathrm{w}$ badanych rodzinach są już przyzwyczajone do stałej obecności mediów w ich otoczeniu, a korzystanie z różnych urządzeń medialnych może stopniowo stać się utrwalonym nawykiem.

Badania te traktuję jako przygotowanie i wskazanie do podjęcia bardziej pogłębionych analiz. Liczba badanych rodzin nie stanowiła reprezentatywnej grupy rodzin z dziećmi w wieku przedszkolnym, ale uzyskane wyniki badań na pewno potwierdziły konieczność podejmowania tej problematyki. Badania $\mathrm{w}$ większej liczbie rodzin, $\mathrm{z}$ bardziej zróżnicowanych środowisk pozwoli mi na szerszą perspektywę oceny rodzinno-domowej edukacji medialnej.

\section{Podsumowanie}

Rodzina jest pierwszym, naturalnym środowiskiem wychowawczym, a przez to staje się również pierwszym wychowawcą, nauczycielem mediów. Rodzice powinni ustalać zasady korzystania z mediów, sami stanowić przykład racjonalnego korzystania z telewizji, komputera czy telefonu, prowadzić rozmowy o przekazach medialnych, najmłodszych odbiorców uczyć relacji z mediami na przykład poprzez zabawę. Edukacja medialna jest narzędziem społecznej, kulturowej i ekonomicznej zmiany, dlatego warto kształtować u dzieci już od najmłodszych lat postawę właściwego odbiorcy, czyli krytycznego, selektywnego wobec treści medialnych, aby jak najszybciej mogły one stać się aktywnym i świadomym podmiotem komunikacji medialnej. Pozwoli to również na nieprzerwany proces budowania kompetencji medialnych u następnych pokoleń odbiorców mediów. Ważne jest także podążanie współczesnych rodziców za szybkim tempem rozwoju nowych technologii, poznawanie możliwości wykorzystania stale doskonalonych narzędzi medialnych. Wiedza ta może też uchronić dorosłych przed reedukacją medialną, która stała się obecnie efektem ubocznym gwałtownego rozwoju medialnej 
cywilizacji. Ponadto, wydaje się wciąż aktualna teza o konieczności zwiększenia udziału formalnych instytucji w edukacji medialnej, rozpoczynając intensywne działania w tym zakresie już w placówkach wychowania przedszkolnego. Również w mediach powinny być prezentowane kampanie społeczne dotyczące zagrożeń dla najmłodszych odbiorców, wynikających z odbieranych treści audiowizualnych, a także programy telewizyjne poświęcone tej problematyce, dedykowane rodzicom i dzieciom.

\section{BIBLIOGRAFIA}

Ang I., Living Room Wars: Rethinking Media Audiences for a Postmodern World, Routledge, London 1996.

Banaszkiewicz K., Nikt nie rodzi się telewidzem. Człowiek, kultura, audiowizualność, Wydawnictwo Nomos, Kraków 2000.

Baudrillard J., Świat wideo i podmiot fraktalny, [w:] Po kinie? Audiowizualność w epoce przekaźników elektronicznych, Wybór, wprowadzenie i opracowanie A. Gwóźdź, Wydawnictwo Universitas, Kraków 1994.

Baudrillard J., Ameryka, przekł. R. Lis, Wydawnictwo Sic!, Warszawa 1998.

Bogunia-Borowska M., Fenomen telewizji. Interpretacje socjologiczne i kulturowe, Wydawnictwo Uniwersytetu Jagiellońskiego, Kraków 2012.

Braun-Gałkowska M., Ulfik I., Zabawa w zabijanie. Oddziaływanie przemocy prezentowanej w mediach na psychike dzieci, Wydawnictwo Krupski i S-ka, Warszawa 2000.

Buckingham D., Children Talking Television: The Making of Television Literacy, Routledge, London 1993.

Condry J.C., Popper K., Telewizja - zagrożenie dla demokracji, przekł. M. Król, Wydawnictwo Sic!, Warszawa 1996.

Elliott M., Jak dbać o bezpieczeństwo dziecka. Praktyczne rady dla rodziców, przekł. K. Kozubal, Książka i Wiedza, Warszawa 1997.

Ellis J., Visible Ficions: Cinema, Television, Video, Routledge, London 1992.

Gajda J., Media w edukacji, Oficyna Wydawnicza Impuls, Kraków 2002.

Goban-Klas T., Media i komunikowanie masowe. Teorie i analizy prasy, radia, telewizji i Internetu, Wydawnictwo Naukowe PWN, Warszawa - Kraków 2001.

Goban-Klas T., Społeczeństwo medialne, Wydawnictwa Szkolne i Pedagogiczne, Warszawa 2005.

Hodge B., Tripp D., Children and Television: A Semiotic Approach, Polity Press, Cambridge 1986.

http:/ / www.europarl.europa.eu, [dostęp: 17.03.2019].

https://www.fisher-price.com, [dostęp: 15.03.2019].

https://www.pi.gov.pl, [dostęp: 17.03.2019].

http:/ / www.krrit.gov.pl, [dostęp: 18.03.2019].

Huesmann L.R., Eron L.D., Cognitive processes and the persistence of aggressive behavior, Aggressive Behavior, 1984, 10, 3.

Izdebska J., Rodzina, dziecko, telewizja. Szanse wychowawcze i zagrożenia telewizji, Wydawnictwo Uniwersyteckie Trans Humana, Białystok 1996.

Izdebska J., Dziecko osamotnione w rodzinie, Wydawnictwo Uniwersyteckie Trans Humana, Białystok 2004. 
Izdebska J., Mass media i multimedia - dominująca przestrzeń życia dziecka, [w:] Pedagogika społeczna, red. E. Marynowicz-Hetka, Wydawnictwo Naukowe PWN, Warszawa 2007.

Juszczyk S., Człowiek w świecie elektronicznych mediów - szanse i zagrożenia, Wydawnictwo Uniwersytetu Śląskiego, Katowice 2000.

Kapuściński R., Internet kontrolowany, Aktualności Telewizyjne, 1999, 2.

Kerckhove D., Powłoka kultury. Odkrywanie nowej elektronicznej rzeczywistości, przekł. W. Sikorski, P. Nowakowski, Wydawnictwo Mikom, Warszawa 1996.

Kłoskowska A., Kultura masowa. Krytyka i obrona, Wydawnictwo Naukowe PWN, Warszawa 2005.

Kossowski P., Dziecko i reklama telewizyjna, Wydawnictwo Akademickie Żak, Warszawa 1999.

Lepa A., Pedagogika mass mediów, Archidiecezjalne Wydawnictwo Łódzkie, Łódź 2000.

Macdonald D., Teoria kultury masowej, [w:] Kultura masowa, Wybór, przekład, przedmowa Cz. Miłosz, Wydawnictwo Literackie, Kraków 2002.

Marynowicz-Hetka E. (red.), Pedagogika społeczna, t. 2, Wydawnictwo Naukowe PWN, Warszawa 2007.

Masterman L., Teaching the media, Routledge, London 1990.

McLuhan M., Wybór pism, Wydawnictwa Artystyczne i Filmowe, Warszawa 1975.

Melosik Z., Kultura popularna jako czynnik socjalizacji, [w:] Pedagogika, t. 2, red. Z. Kwieciński, B. Śliwerski, Wydawnictwo Naukowe PWN, Warszawa 2003.

Morley D., Sposoby rodzinnego oglądania telewizji - zróżnicowanie ze względu na płeć, [w:] Gender w kinie europejskim i mediach, red. E. Ostrowska, Wydawnictwo Rabid, Kraków 2001.

Mrozowski M., Efekt trzeciej osoby, czyli postrzeganie podatności innych ludzi na wptyw mediów masowych, Studia Medioznawcze, 2003, 4(14).

Postman N., Technopol - triumftechniki nad kultura, Państwowy Instytut Wydawniczy, Warszawa 1995.

Rajewski M., Media studies a antropologia środków przekazu - próba charakterystyki, [w:] Media studies. Refleksja nad stanem obecnym, red. K. Stępnik, M. Rajewski, Wydawnictwo UMCS, Lublin 2008.

Rivers W. L., Mathews C., Etyka środków przekazu, przekł. J. Zakrzewski, E. Krasnodębska, Wydawnictwa Artystyczne i Filmowe, Warszawa 1995.

Sugier-Szerega A., Ksztattowanie kompetencji medialnej u dzieci w wieku przedszkolnym - szanse, trudności, ograniczenia, [w:] Edukacja medialna w dobie wspótczesnych zmian kulturowych, społecznych i technologicznych, red. A. Ogonowska, G. Ptaszek, Oficyna Wydawnicza Impuls, Kraków 2015.

Szkudlarek T., Media. Szkic z filozofii i pedagogiki dystansu, Oficyna Wydawnicza Impuls, Kraków 1999.

Tadeusiewicz R., Smog informacyjny, PAN, Prace Komisji Zagrożeń Cywilizacyjnych, t. 2, 1999, www.academia.edu [dostęp: 10.03.2019].

Wright J.C., Huston A.C., Reitz A.L., Piemyat S., Young children's Perceptions of Television Reality: Determinants and Developmental Differences, Developmental Psychology, 1994, 30,2 . 